\title{
Reporting the Fantastic: Deferral and Pan-determinism in Ugo Tarchetti
}

\begin{abstract}
This article explores how Ugo Tarchetti balances between the fantastic and the real in his narratives through explicit real-world location together with a deferral of the impossible. I argue that Tarchetti allows the fantastic and the real to coexist by enclosing the fantastic with reassuring markers, deferring its authenticity to lost manuscripts, or for the narrator to simply claim to be passing on a story. Additionally, I make the case that Tarchetti's use of pan-determinism complements this effect, and that as well as balancing the real with the fantastic, he is also representing the new social reality of the rise of practices such as spiritualism in late nineteenth century Italy.
\end{abstract}

Keywords: Ugo Tarchetti, fantastic, deferral, pan-determinism, spiritualism.

\section{Introduction}

Ugo Tarchetti is widely considered to be the first writer of the fantastic in Italy, the 'vero padre del genere fantastico in Italia'. ${ }^{1}$ As Moretti points out, '[p]rima della pubblicazione dei Racconti fantastici tarchettiani è arduo ritrovare nella letteratura italiana dell'Ottocento quei temi definiti dal Todorov tipici del genere "fantastique $»^{2}{ }^{2}$ Certainly Tarchetti's Racconti fantastici (1869) is the first instance of a collection of stories which demonstrates a more systematic approach to fantastic literature, as opposed to occasional, ephemeral stories more typical (but not exclusively so) of the fantastic in Italy over the course of the nineteenth and twentieth centuries. ${ }^{3}$ However, Tarchetti's status as a 'father' figure is predominantly from a diachronic perspective and not in terms of any literary authority. ${ }^{4}$

During the period when Racconti fantastici was published, the demands of literature were towards realistic modes of representation as well as towards political and ethical questions bound up with the Unification. As Ghidetti and Lattarulo argue, '[n]on si può infatti dimenticare che continuano a pesare sulla letteratura italiana, dall'età del decadentismo al secondo dopoguerra, urgenze etiche e politiche attivate sulla scia del Risorgimento'. ${ }^{5}$ The late nineteenth century was therefore a difficult environment for the fantastic in Italy, which for the most part avoided such questions. Against this backdrop, Venuti contends that through the fantastic Tarchetti sets out to challenge and question the hegemony of realistic representation, its formal conventions and its bourgeois ideological underpinnings. ${ }^{6}$ This is an argument made more widely of fantastic literature, for example by Jackson, for whom the fantastic as a whole 'exists as the inside, or underside, of realism' that attacks 'a 'bourgeois' category of the real'. ${ }^{7}$ Tarchetti indeed engages with realistic discourse, and the argument can be made that his narratives are subversive in a manner that Venuti proposes, but I will instead claim that Tarchetti's fantastic prose - here taken to mean the extraordinary and impossible in his fiction - is more tempered, less confrontational and less antagonistic towards a realistic discourse than Venuti maintains for Tarchetti and less confrontational towards realism than Jackson advocates is characteristic of fantastic narrative more broadly.

In combination with the fantastic, Tarchetti's fiction is exemplary of a larger binary trend in Scapigliati texts, that of focusing on, as Finzi maintains, 'il sogno, l'ombra, quanto di oscuro e inspiegabile è nell'esistere, l'extravisuale [...], l'oltremondo e certi fenomeni occulti [...], ma sempre con l'aria di chi non perde mai di vista quella forma del sensibile che ci troviamo a toccare/vedere/vivere'. ${ }^{8}$ The duality (or 'dualismo' ${ }^{9}$ as Finzi notes) between empirical observation and fantastic component is also noted by Ruchin who observes that 
'[e]sistono, per Iginio, due coppie oppositive: materia/reale contro spirito/fantastico' and terms it 'complementarietà', 'un nuovo doppio tarchettiano che coinvolge reale e fantastico insieme' ${ }^{10}$ This coexistence of the possible and impossible is moreover found in other stories like 'L'elixir dell'immortalità', 'Re per ventiquattrore', and 'Riccardo Waitzen'.

This article is divided into two sections. ${ }^{11}$ In the first, I show that one way that coexistence is achieved is by deferring the fantastic so that it does not conflict directly with the real in the narrator's present moment. Rather than give a vague non-specific setting within which to introduce the impossible, Tarchetti clearly and explicitly locates his stories with realworld chronological and geographical coordinates and defers the fantastic, thus making the distance between narrative location and deferral overt. Additionally, and challenging the label of subversive fiction, I will argue that the fantastic in Tarchetti's narrative paradoxically functions to record the real, not undermine it. During the second half of the nineteenth century, pseudoscientific practices such as magnetism and in particular spiritualism were growing in popularity in Italy. In some of his narratives, Tarchetti represents the historical beginnings of an alternative reality of pseudoscience, where the supernatural is legitimated through a refashioned positivism (such as in 'Riccardo Waitzen' and 'Un osso di morto'), one whose reach as a science is extended to include the impossible. The impossible is not therefore seen as distinct from the real but rather as an addition to what is perceived as possible. As Ghidetti points out, pseudoscience was still a minor cultural moment when Tarchetti was writing, 'quando ancora, tutto sommato, lo spiritismo «scientifico» aveva scarsa udienza in Italia', ${ }^{12}$ and Tarchetti himself

had experimented with mesmerism, hypnotism, and animal magnetism in addition to keeping himself informed of the latest accounts of preternatural experiences in Italy; he was familiar with, for example, Teofilo Coreni's Annals of Spiritism, which was published in 1864 and which circulated in Italy and in Europe. ${ }^{13}$

In his stories, however, there is no systematic position towards the impossible; protagonists and narrators both accept and reject the supernatural. Ruchin concurs: 'Tarchetti sperimenterà, nel corpus delle opere a cui accennavamo [his fantastic stories], queste nuove dottrine in modo come sempre alterno: ora abbracciandole entusiasticamente, ora allontanandosene sospettoso ed impaurito'. ${ }^{14}$ This oscillation between scepticism and acceptance of the supernatural by extension reflects the early cultural moment of pseudoscience in Italy, and, moreover, balances the real and the impossible within the stories.

In the second part of the article, I will make a third argument that pan-determinism complements the deferral of the fantastic. A Todorovian term, pan-determinism proposes that everything in a fantastic narrative has a cause linked to a larger series of events, removing chance, luck or coincidence, resulting in an overarching structure of connections. As Todorov puts it, "everything, down to the encounter of various causal series (or "chance") must have its cause, in the full sense of the word, even if this cause can only be of a supernatural order'. ${ }^{15}$ Todorov explores some examples by Nerval and Gautier, eventually concluding:

we touch a ring and candles flare up, we throw the ring and a flood recedes. In other words, on the most abstract level, pan-determinism signifies that the limit between the physical and the mental, between matter and spirit, between word and thing, ceases to be impervious. ${ }^{16}$

With pan-determinism, the supernatural is, in essence, confirmed, but that does not mean that an explanation or further clarification is forthcoming. The existence of the impossible is for the most part confirmed by Tarchetti's characters, and pan-determinism is both a way of corroborating the fantastic and a way of avoiding having to directly legitimate it because pan- 
determinism provides a clear - although at times simplistic - displacement of the source of the fantastic, for example to an omnipotent deity ('Il lago delle tre lamprede') or to a hidden structure of cause and effect ('La lettera U').

\section{Locating the Real, Deferring the Impossible}

Each fantastic story of Tarchetti's (which here includes the insanity of 'La lettera $U$ ' and the dream world of 'Re per ventiquattrore') either has a date or time signpost or, often, both. Beginning with the Racconti fantastici, 'I fatali' coordinates are given as '[n]el carnevale del $1866 \mathrm{mi}$ trovava [sic] a Milano'; ${ }^{17}$ in 'Le leggende del castello nero', '[n]el 1830 io aveva [sic] quindici anni, e conviveva colla famiglia in una grossa borgata del Tirolo'; ${ }^{18}$ in 'La lettera U', '[I]'infelice che vergò queste linee, morí nel manicomio di Milano l'11 settembre 1865'; ${ }^{19}$ in 'Un osso di morto', '[n]el 1855, domiciliatomi a Pavia', ${ }^{20}$ and in 'Uno spirito in un lampone', '[n]el 1854 un avvenimento prodigioso riempí di terrore e di meraviglia tutta la semplice popolazione d'un piccolo villaggio della Calabria. ${ }^{21}$ This trend extends to Tarchetti's other narratives, where in 'L'elixir dell'immortalità (Imitazione dall'inglese)', the date of the account is 'Dicembre 16, 1867', 22 and in 'in Riccardo Waitzen', '[i]n un caldo mattino di agosto dell'anno 1840, un elegante calesse tirato da due cavalli amburghesi, sollevava un nembo di polvere sulla via che da Raab mena a Vienna. ${ }^{23}$ One exception is 'Re per ventiquattrore', which is in turn the only entirely oneiric narrative, and where no real-world coordinates are given outside of the dream world; within, there is a date of arrival, '[il] ventisette aprile milleottocentosessantadue'. ${ }^{24}$

Further realistic touches ${ }^{25}$ to the meticulous and systematic chronicling of the narratives spaces and times, together with the café Martini in 'I fatali' which Roda ${ }^{26}$ and Bonifazi both note was the Scapigliati's café in real life - a 'superbo tocco realistico' ${ }^{27}$-, come in the form of references to real-world figures such as Mesmer in 'I fatali' and 'Riccardo Waitzen', and Cornelius from 'L'elixir dell'immortalità'. ${ }^{28}$ The reason why this technique of rigorously locating the stories is important to note is that it goes against a certain gothic tendency of deferring where the plot unfolds away from recognisable spaces. In turn, it is useful to consider these axioms of gothic space as a conceptual framework for Tarchetti because, rather than displacing the locus of the impossible, his explicit real-world coordinates lay the groundwork for the coexistence of the possible and impossible. Rather than setting the impossible a safe distance from everyday norms, it is rather intertwined with them, unlike in early gothic narratives, where

[t]he major locus of Gothic plots, the castle, was gloomily predominant in early Gothic fiction. [...] Architecture, particularly medieval in form (although historical accuracy was not a prime concern), signalled the spatial and temporal separation of the past and its values from those of the present. $^{29}$

Elsewhere Botting draws from Foucault's concept of heterotopia to discuss the concept of gothic space in wider terms.

For Foucault, a heterotopia, in contrast to a utopia, is a 'counter-site', an 'effectively enacted utopia' in which the real sites of culture are 'represented, contested, inverted'. The main features of Gothic fiction, in neoclassical terms, are heterotopias: the wild landscapes, the ruined castles and abbeys, the dark, dank labyrinths, the marvellous, supernatural events, distant times and customs [...]. ${ }^{30}$ 
The early gothic novel is spatially and temporally separated and inverted, ${ }^{31}$ displaced from sites of quotidian norms. Caesar concurs, '[d]isplacement is at the heart of the gothic novel, where demarcation of place has a singularly important role. Be it castle, ruin, monastery, family pile [...], it is always in some way cut off from its surroundings' ${ }^{32}$ However, in later nineteenth century gothic novels, 'the castles and counts [...] give way to narratives whose action centres on urban, domestic, commercial and professional figures and locales', ${ }^{33}$ which 'give way to terrors and horrors that are much closer to home, uncanny disruptions of the boundaries between inside and outside, reality and delusion [...], materialism and spirituality'. ${ }^{34}$

Through their historical and geographical coordinates, many of Tarchetti's stories conform to this modernising movement to urban spaces. 'Le leggende del castello nero' is an exception in Tarchetti: it is a story which resonates with both eighteenth and nineteenth century gothic axioms of space, with a homely site of the waking action, but a historically and spatially displaced setting of the castle during Arturo's dream sequences. Moreover, Tarchetti's fairytales are set 'south' from a northern Milan milieu: events surrounding the Baron of $\mathrm{B}^{35}$ in 'Uno spirito in un lampone' take place in Calabria; and 'Il lago delle tre lamprede', although hardly gothic, is likewise set in the Italian south. For the most part, however, Tarchetti's stories fit within a more modern rather than neoclassical conception of the gothic space, where the locus where the impossible is found overlaps and coexists with the spaces of the real, blurring the boundaries between them, and which adds to the complementary and dualistic characteristics that Ruchin and Finzi argue are present in Tarchetti's prose. ${ }^{36}$

In turn, there is little radical incompatibility of the impossible and possible in Tarchetti of the sort that would evoke, for example, hesitation. This is not to say that the possible and impossible coexist in harmony. On the one hand, the impossible is for the most part confirmed (or the characters accept it as such), yet on the other, in each story further explanation, responsibility for authenticity, or for being the source of the fantastic is never the story itself. In the same way that Tarchetti systematically locates his stories, so too is the fantastic within them displaced elsewhere. Tarchetti does not set the fantastic away from the everyday norms of a realistic world, but rather places them side-by-side, instead providing a means to circumvent the impossible.

The narrator of 'I fatali' relays the facts of the story, and defers the legitimacy of the story to the reader, '[i]o non voglio dimostrarne né l'assurdo, né la verità. Credo che nessuno lo possa fare con argomenti autorevoli. Mi limito a raccontare fatti che hanno rapporto con questa superstizione'. ${ }^{37} \mathrm{He}$ retrospectively notes at the end that '[s]ono scorsi due anni dalla data di questo avvenimento, e nessuna luce fu fatta su questo delitto': ${ }^{38}$ no explanation is forthcoming, merely a reporting of fantastic events within a small and enclosed timeframe, which do not intrude into the present moment of the narrator.

A purported visionary, the protagonist of 'La lettera $U$ ' declares himself to be capable of seeing the fate of humanity linked to the letter $u$, which he has written down in the form of a manuscript, 'un lavoro voluminoso, nel quale mi proponeva di dimostrare come tutte le umane calamità non procedessero da altre cause che dall'esistenza dell'U' ${ }^{39}$ However, this manuscript, which contains the information necessary to legitimate his claim of superhuman foresight, is missing - precisely deferred - as the madman himself is likewise spatially separate from the rest of Milan, cut off from the city within the walls of the asylum, a Tarchettian heterotopia. The revelation at the end that the manuscript of the story was written by a patient, '[l]'infelice che vergò queste linee, morí nel manicomio di Milano l'11 settembre 1865 ', together with the subtitle of 'Manoscritto d'un pazzo', ${ }^{40}$ demarcate the protagonist's rants much like the physical space of the asylum separates the madman from the rest of society. Rather than madness as subversive or dangerous behaviour, these markers reassure, 
signalling 'reason at work' ${ }^{41}$ Stating that he was born with a $\mathrm{u}$ in his name distinguishes the narrator from the author: the name Ugo is added in reverence to Ugo Foscolo later during Tarchetti's life, ${ }^{42}$ yet the narrator was born with a u, '[i]o nacqui predestinato'. ${ }^{43}$ In the same way that the source of the text is deferred - it is found by (presumably) one of the asylum staff - so too is the character: it is not Tarchetti but a Tarchetti-esque character with a $u$ in his name that tells the story.

'Le leggende del castello nero' comprises three tiers of deferral; firstly, at the end of the story, a further character introduces themselves, stating that

[l]'autore di queste memorie, che fu mio amico e letterato di qualche fama, proseguendo il suo viaggio verso l'interno della Germania, morí il venti gennaio 1850 [...]. lo ho trovate queste pagine tra i suoi molti manoscritti, e le ho pubblicate. ${ }^{44}$

The third party is passing down a manuscript of a reported fantastic story, and events take place in Arturo's dreams, not in his waking world. Secondly, displacing the fantastic to a dream world is also a technique deployed in 'Re per ventiquattrore', but in this case there is a subtle difference. Arturo's dreams are not separate dream worlds, but rather occasions when he travels back in time to meet his ancestors, events which are recorded in the two-volume family history. In other words, Arturo is dreaming and also goes back along his real family timeline. The explanation of 'it was just a dream' is therefore not strictly speaking a legitimate one. Thirdly, the volume of the family history is eventually found burnt in the hearth, now absent, like the madman's manifesto.

As with 'I fatali', the reader is left to decide the validity of the story of 'Un osso di morto', '[l]ascio a chi mi legge l'apprezzamento del fatto inesplicabile che sto per raccontare'. ${ }^{45}$ The narrator is not an eyewitness in 'Uno spirito in un lampone', where the incarcerated gardener tells of how he killed Clara the maid. This does not prove the supernatural presence of Clara's ghost, but its authenticity is inferred because her body is found as a result of Clara's ghost accusing her murderer. If it were not for the ghost, the gardener would not have been caught.

A distinct change in tone pervades the folktale 'Il lago delle tre lamprede' (as the subtitle 'tradizione popolare' suggests), '[q]uivi sono luoghi memorabili per antichità e per tradizioni popolari'. ${ }^{46}$ Ghidetti supposes that Tarchetti learnt of this tale when he was posted to the Italian south, a 'leggenda che probabilmente il Tarchetti aveva appreso durante la sua permanenza nel mezzogiorno $d^{\prime} \mid{ }^{\prime}$ talia', ${ }^{47}$ and thus Tarchetti is once again merely the reporter.

With a similar setting of a distant past, 'L'elixir dell'immortalità' is the story of a threehundred-and-twenty-year-old man who has written the account of his life for future generations. Recourse to an old manuscript or to a third character who discovers the account is absent. Rather, the story is implicitly passed down, '[v]oglio raccontare la mia storia', ${ }^{48}$ 'veniamo al mio racconto', 49 and the narrator writes as an eternal twenty-year-old, 'tutta la mia persona continuava ad essere cosí intatta come nel mio ventesimo anno'. ${ }^{50}$ Somewhat conveniently, therefore, there is no proof of his extraordinary age, and writing much closer to the real present in which this story was published (1867), the elixir is a historical artefact, its creator dead, and the impossible has been left behind in the Renaissance.

It is the real world that is deferred in the dream world of 'Re per ventiquattrore', ${ }^{51}$ and the plot is moreover dislocated spatially where the narrator arrives on the island of Potikoros to claim the throne left to him by his father. Roda ${ }^{52}$ and Guglielminetti ${ }^{53}$ both label the story as utopian, but whilst Potikoros is certainly an island paradise with 'tutte le delizie favolose dell'Eden', ${ }^{54}$ it is by no means an ideal or 'good' society (from the Greek 'eu-topos' meaning 'good place'). However, it is dislocated, not quite a utopian no-place ('ou-topos'), but still distant from Italy. 'La grande isola di Potikoros giace nell'Oceano equinoziale, al trentesimo 
grado di latitudine, non molto lontana dal piccolo Arcipelago dei Navigatori' ${ }^{55}$ Bettini furthers this argument by noting a cultural as well as geographical displacement: 'un nome inverosimile, Potikoros, che tende a sfumare l'immediata collocazione geografica [...] di una civiltà mai conosciuta'. ${ }^{56}$

Together with 'I fatali' and 'Le leggende del castello nero' to some extent, 'Riccardo Waitzen' begins with an introductory (and here disparaging) preamble on pseudoscience, where he maintains the importance of scepticism, 'il dubbio è la rivelazione della scienza [...] poiché una sola fede esiste, quella del dubbio'. ${ }^{57}$ Rather than explicitly stating that either the reader is free to make up their mind, or that the story is dislocated in time or space, in 'Riccardo Waitzen' - Tarchetti's most subtle example of deferring the fantastic - , doubt is instead quietly encouraged, and any responsibility for accepting the subsequent story about the ghost of Anna no longer lies with the narrator.

Ghidetti rightly points out that the narrator of each of the Racconti fantastici demonstrates 'la volontà di apparire soltanto come espositore di fatti straordinari che richiedono un atto di fede per essere creduti, anche nel caso che l'autore narri avvenimenti di cui è stato protagonista in prima persona' ${ }^{58}$ Concurring, Santoro adds that 'il filtro della testimonianza assume una funzione di distacco dal piano dell'irrazionale puro o dell'inesplicabile, ${ }^{59}$ whereas from a different perspective, Bosco argues that the Racconti fantastici

prendono anche la forma esterna della relazione di un fatto in appoggio a una tesi generale (il « caso clinico " concreto che illustra una malattia della quale si siano preliminarmente descritte le caratteristiche generali): si vedano le considerazioni che aprono i primi due e maggiori Racconti; si veda che l'esordio di Un osso di morto: « Lascio a chi mi legge l'apprezzamento del fatto inesplicabile che sto per raccontare »: qui il medico si limita a esporre il " caso », senza trarne apparentemente conclusioni : ma lo espone in vista di esse conclusioni. ${ }^{60}$

Although broadly the same as Ghidetti's argument, Bosco separates the fantastic from the real, as though Tarchetti seeks to discredit the validity of his own stories because they are deficient or abnormal. However, I would instead maintain that reporting the facts as they are 'found' is a means to negotiate how the real and fantastic interact because without any claim to authenticity (but merely reporting), the fantastic does not directly impinge upon the real. What Bosco, Ghidetti, and Santoro demonstrate is a distance between narrator and event, an argument which can be extended to the rest of Tarchetti's fantastic stories. However, while the fantastic and the real co-exist in the same narratives, a yardstick of the real - and by extension, an implicit suggestion that the fantastic is not a dangerously subversive component here - is always present because discussing the fantastic in these distanced and deferred terms, yet also within the same spaces of the normal lives of characters, Tarchetti's narratives signal 'reason at work'. The tendency to defer is therefore a means to introduce the fantastic without radically undermining the real in each story as the fantastic is enclosed by reassuring markers. While the claims of the fantastic are made, the supporting evidence is lost, or the story has been passed down from another time or place.

Three stories that represent the pseudoscientific practices which were becoming popular in Italy distinguish themselves by the nature of the relationship of the coexistence between the real and the fantastic present within them. Firstly, 'I fatali' begins with a reflection on the limits of science where Tarchetti questions the basis upon which knowledge of the world is constructed:

la scienza ha analizzato la natura; i suoi sistemi, le sue leggi, le sue influenze ci sono quasi tutte note: ma essa si è arrestata dinanzi ai fenomeni psicologici, e dinanzi ai rapporti che 
congiungono questi a quelli. Essa non ha potuto avanzarsi di piú, e ha trattenuto le nostre credenze sulla soglia di questo regno inesplorato. ${ }^{61}$

Tarchetti's musings create a literary space for the fantastic - and it is significant that the first of Tarchetti's Racconti fantastici does so -, and his allusion to the possibilities afforded by pseudoscience, the 'regno inesplorato', is taken further in 'Riccardo Waitzen'. Here, Tarchetti discusses pseudoscientific topics including mesmerism, spiritualism and magnetism, albeit unsystematically ('alla rinfusa' ${ }^{\text {'62 }}$ ) and, despite urging doubt, acknowledges one pseudoscientific practice with merit, '[c]iò non di meno, una vaga, una poetica illusione è venuta oggi a mettere in rapporto il mondo fisico col mondo spirituale [...] intendo parlare dello spiritismo, questa applicazione singolare della scienza'. ${ }^{63}$ Spiritualism is also addressed 'Un osso di morto', where, at a séance, the narrator is so impressed that he decides to question a dead friend and professor 'sul destino umano, e sulla spiritualità della nostra natura'. ${ }^{64}$ However, spiritualism in 'Un osso di morto' is not taken altogether seriously; instead, the visitation descends into banality and small talk rather than the profound questions the narrator had hoped to ask, and the ghost of the professor Federico $M$, 'scettico profondamente e inguaribilmente' ${ }^{65}$ is now ironically the very 'embodiment' of what he once doubted.

As Ruchin notes, during the second half of the nineteenth century, Tarchetti was not the only author to be attracted to this subject of the paranormal (although he was among the earliest, as Ghidetti has already remarked).

Molti autori, fedeli seguaci delle nuove scienze, non si preoccupano più di ciò che sarà, ma di ciò che potrebbe essere; e in questa frenetica ricerca si gettano nello sconosciuto; in questo nuovo pianeta trovano fedi meno ufficiali ma accattivanti: la magia, l'occultismo, la cabala, il mesmerismo, l'ipnotismo, che creano disagio ed interesse allo stesso tempo. ${ }^{66}$

Colin furthermore stresses the reconcilable rather than incompatible nature of positivism proper and the belief systems which appropriated it.

Loin de s'opposer irrémédiablement, la science positiviste et les croyances dans un au-delà magnétique ou spiritique auraient souvent coexisté en Italie, en trouvant des adhérents chez les mêmes intellectuels. Le cas de Capuana, écrivain naturaliste ayant aussi composé des essais sur les sciences occultes et les théories spiritistes, est loin d'être une exception [...]. ${ }^{67}$

What these three narratives by Tarchetti demonstrate is a mediation between unquestioning acceptance and doubt, which in turn reflects the cultural attitude towards pseudoscience in the later part of the nineteenth century in Italy: some were sceptical, others accepting of the impossible. As well as balancing the real and fantastic through deferral, Tarchetti is also at times representing the social reality around him, not simply undermining realism.

\section{Pan-determinism}

Pan-determinism takes different forms in Tarchetti, and there is moreover little consistency in the manner in which it is deployed. Moretti identifies pan-determinism in 'I fatali', 'non è qui un elemento tematico, ma strutturale'; ${ }^{68}$ and more precisely, this story deals with predestination - indeed the very title is pan-deterministic. Believing that certain events were meant to take place, the young Saternez forgives the suspicious Davide's attempt to have him dispatched by the mysterious Sagrezwitch because he (Saternez) thinks he is already meant to meet his adversary, '[q]uell'uomo ed io ci conoscevamo da tempo, fors'anche ci cercavamo 
[...]. II nostro incontro era inevitabile perché era predestinato' ${ }^{69}$ Saternez therefore forgives the actions of the narrator and Davide because '[v]oi non siete stati che un mezzo nelle mani della fatalită'. ${ }^{70}$ Earlier, when Davide writes to the narrator revealing that the two men know each other, Davide provides a similar explanation, '[i]o non poteva [sic] né prevedere, né arrestare gli avvenimenti che dovranno compiersi; è la mano della fatalità che li aveva preparati'. ${ }^{71}$ In this, predestination absolves Davide and the narrator from any moral responsibility of causing the death of Saternez in order to prevent the death of a woman they all love, Silvia.

Predestination moreover clears up an ambiguity regarding the powers that both Saternez and Sagrezwitch possess: the mesmeric spheres of influence which they appear to exude with fatal consequences. The narrator asks, '[e]sistono realmente esseri destinati ad esercitare un'influenza sinistra sugli uomini e sulle cose che li circondano?'. ${ }^{72}$ Those who come into close proximity to either man fall ill or die shortly afterwards, but there is little conclusive evidence of the effect of these powers: the boy in the street who is knocked down ${ }^{73}$ and the girl at the theatre who falls ill ${ }^{74}$ could be coincidental events. However, as pan-determinism eliminates chance and coincidence, if predestination is accepted in 'I fatali', it follows that the effects of the spheres of influence exist and cannot be explained away by coincidence.

When Saternez's body is found, the newspapers reveal his real name to be 'Gustavo dei conti di Sagrezwitch' ${ }^{75}$ Bonifazi argues that, since one is Corrado di Sagrezwitch and the murdered man is Gustavo di Sagrezwitch, 'lo schema può indicare anche l'inutile tentativo del figlio di distaccarsi dal padre e dal suo nome'. ${ }^{76}$ This is a convincing argument because it firstly demonstrates how these two men know each other, and also suggests that their powers are hereditary, explaining how they could share such singular powers. Bonifazi further maintains that the murder takes places because the father had forbidden his son to indulge his desires, ${ }^{77}$ which thereby weakens the claim of supernatural predestination because Saternez knows he will eventually die by his father's hand, not because of supernatural forces over which he has no control, but simply because he has disobeyed his father.

Similarly, Davide's prediction that 'se l'esistenza di questo potere è verace, l'uno dovrà distruggere l'altro, la disparità delle forze cagionerà lo squilibrio; la sconfitta del piú debole è inevitabile ${ }^{78}$ is incorrect as Saternez dies by a knife through his heart rather by supernatural means. In this way, further evidence of their powers is weakened by a material explanation, in the same way that predestination is weakened by the motives behind the actions of Saternez and Sagrezwitch. This is not to negate the existence of either the mesmeric powers or predestination, but rather reflects the balance between the fantastic and the real that Tarchetti is keen to provide to the story - and that the narrator makes clear at the beginning - as well as throughout his works.

Pan-determinism in 'La lettera $U$ ' is less convincing, not only because of the qualification that it is written by a madman ('Manoscritto d'un pazzo'), but also because the narrator fails to demonstrate its effect. The omnipresence of the letter $u$ leads the narrator to see patterns,

[e]ntrai in una nuova sfera di osservazioni, in una sfera piú elevata, piú attiva: studiai i rapporti che legavano ai destini dell'umanità questa lettera fatale; ne trovai tutte le fila, ne scopersi tutte le cause, ne indovinai tutte le leggi [...]. ${ }^{79}$

Rather than a madman who is deficient of reason, the narrator considers himself a visionary. The claim of having discovered the links between the letter $u$ and human destiny is pandeterministic (because the concept of destiny is necessarily pan-deterministic as events are foreseen and therefore have no recourse to coincidence), but is deferred since the narrator never reveals his manuscript. Words which resonate with the theme of pan-determinism 
appear throughout the story, 'profili fatali', 'segno fatale', 'I'influenza', 'predestinato', 'destini', but these same words in other Tarchetti stories such as 'I fatali' carry a greater weight because such supernatural occurrences are at least discussed outside of an asylum; within, they articulate the haphazard and delirious writings of a patient.

One of the simplest but also most facile ways of articulating pan-determinism is demonstrated in 'Il lago delle tre lamprede': recourse to an omnipotent deity, 'il Signore'. In a forest in the Mezzogiorno, the narrator finds himself inexplicably walking in circles. He is rescued by a local who recounts the story of the lake where there used to be a convent, in which three hermits lived. When an old man, in fact God in disguise, calls begging for water, he is turned away, upon which he transforms the hermits into lampreys, and the convent into a lake, ${ }^{80}$ bewitching the whole area.

Events within narrative dream sequences are also pan-deterministic devices because they are derived from, and attributable to, the control of the mind of the dreamer. ${ }^{81}$ 'Re per ventiquattrore' is just such an example, where the narrator dreams he inherits the island of Potikoros and wakes up just as he is being executed, after which he is informed that he was asleep.

Finally, Tarchetti's 'Riccardo Waitzen' is not an entirely pan-deterministic story. The ghost of Riccardo's dead love Anna is summoned by playing Hummel's symphony, and her presence, an 'inquietante ubiquità' ${ }^{82}$ as Roda puts it, creates an environment of surveillance for Riccardo who is literally haunted by the memory of his dead love, a justified fantastic form of paranoia because he is being followed. Furthermore, Anna's presence in Riccardo's life is a more convincing pan-determinism than in the world of 'I fatali' because she demonstrates her power to watch and affect Riccardo's mind and the world around him, whereas in 'I fatali', there are material explanations to counter the claims of predestination. Importantly, Anna does not control the whole narrative world, but only the circumstances concerning Riccardo, a delimited not pan-determinism. Predestination also features in 'Riccardo Waitzen', but in a more limited sense of 'essi erano nati l'uno per l'altro' ${ }^{83}$ rather than in a manner similar to the destined conflict of the son with the father in 'I fatali'.

In Tarchetti's stories, pan-determinism functions as a legitimating but displacing mechanism because the explanation to the unknown force or higher power that confirms (or attempts to confirm) the fantastic within the narrative is itself beyond the control and understanding of the protagonists. However, it is not as a whole deployed in a convincing manner. Ruchin neatly summarises the weak effect of pan-determinism in Tarchetti: '[f]atalità, destino, caso, predestinazione, sorte, influenza, ecc.., rappresentano la vasta tavolozza di colori che Tarchetti utilizza in tutte le sue opere per un affresco finale che non è ben definito'. ${ }^{84}$ Importantly, Ruchin does not label these devices pan-deterministic, for which 'caso' should therefore be excluded for the purposes of this discussion. The wider pan-deterministic structures which implement the fantastic are left unexplored, such as in 'Il lago delle tre lamprede'; subtly weakened in 'I fatali'; or entirely separated from the narrative, such as in 'Re per ventiquattrore'.

\section{Conclusions}

After systematic and clear signposts indicating a space and time, together with the real-world assumptions which accompany them, Tarchetti defers the source of his stories. Legitimation of the fantastic is either found elsewhere or it is left up to the reader to decide, and so Tarchetti is able to juxtapose a realistic world with fantastic elements because the fantastic is not explicitly confrontational with the real with which it coexists. Tarchetti's use of pandeterminism, in its various forms, likewise displaces responsibility for confirming the impossible by recourse to an unknown order. On the one hand, a deferred fantastic alludes to 
a sceptical readership that would doubt the supernatural occurrences in the stories; on the other, Tarchetti lived at the beginning of a cultural moment when pseudoscientific practices were growing in popularity. Tarchetti's balance between the real and the fantastic is therefore a means of representing this alternative reality, instead of subverting codes of realistic representation, whilst concurrently acknowledging another, sceptical, readership. His own position, as Ruchin notes above, is inconsistent, and varies between paranormal practitioner and sceptic. His dual technique of locating and deferring, together with the balance between certainty and doubt regarding the impossible, and the historical and cultural circumstances of the late nineteenth century, suggest that Tarchetti writes with a degree of caution that avoids setting up a direct conflict between the real and impossible. He is always careful not to stray too far into unknown territory, which is a further indication that Tarchetti is the first to take to writing fantastic stories in Italy, and he pays attention to counterbalancing the impossible with a means to disregard or dismiss it. This care should not be taken as timidity, however, but rather as an indication of the tempered nature of his fantastic, and should not detract from Tarchetti's importance as an innovative pioneer in Italian letters at a historical moment when the fantastic was still new.

\section{$\underline{\text { Notes }}$}

\footnotetext{
${ }^{1}$ Vittorio Roda, Studi sul fantastico (Bologna: CLUEB, 2009), p. 11.

2 Vincenzo Moretti, 'Igino Ugo Tarchetti e il racconto fantastico', in Igino Ugo Tarchetti e la Scapigliatura: atti del convegno nazionale, S. Salvatore Monferrato, 1-3 ottobre 1976 (Alessandria: Cassa di Risparmio, 1977), (103- 114) p. 103. However, Melani proposes some antecedents to Tarchetti, among whom she cites Diodata Saluzzo's II castello di Bagnasco (1819) and Giovan Battista Bazzoni's Il sotterraneo di Porta nuova (1832), but admits these texts are 'ormai più che dimenticati'. Fantastico italiano: racconti fantastici dell'Ottocento e del primo Novecento italiano, ed. by Costanza Melani (MilanMilan: Rizzoli, 2009), p. 41.

${ }^{3}$ For recent studies on the fantastic in Italy, see Stefano Lazzarin, L'Ombre et la forme: du fantastique italien au XXe siècle (Caen: Presses universitaires de Caen, 2004); Danielle Hipkins, Contemporary Italian Women Writers and Traces of the Fantastic (London: Legenda, 2007); The Italian Gothic and Fantastic: Encounters and Rewritings of Narrative Traditions, ed. by Francesca Billiani and Gigliola Sulis (Madison, NJ: Fairleigh Dickinson University Press, 2007); and Italia magica: letteratura fantastica e surreale dell'Ottocento e del Novecento: atti del convegno, Cagliari-Pula 7-10 giugno 2006, ed. by Giovanna Caltagirone and Sandro Maxia (Cagliari: AM \& D, 2008).

${ }^{4}$ As Bonifazi notes, 'Tarchetti era privo di modelli nostrani e ricorse senza scrupoli agli stranieri'. Neuro Bonifazi, Teoria del fantastico e il racconto fantastico in Italia: Tarchetti - Pirandello - Buzzati (Ravenna: Longo, 1982), p. 79. In the case of 'L'elixir dell'immortalità', Tarchetti directly plagiarises the short story The Mortal Immortal by Mary Shelley (1833). See Lawrence Venuti, 'I. U. Tarchetti's Politics of Translation; or a Plagiarism of Mary Shelley', in Rethinking Translation: Discourse, Subjectivity, Ideology, ed. by Lawrence Venuti (London; New York: Routledge, 1992), pp. 196-230, and Michael McLoughlin, 'Tarchetti traduttore/traditore: L'elixir d'immortalità e The Mortal Immortal di Mary Wollstonecraft Shelley', Giornale storico della letteratura Italiana, 170 (1993), 431-35.

${ }^{5}$ Notturno italiano: racconti fantastici del Novecento, ed. by Enrico Ghidetti and Leonardo Lattarulo (Rome: Riuniti, 1984), vii.

${ }^{6}$ Venuti, 'I. U. Tarchetti's Politics of Translation', p. 197.

${ }^{7}$ Rosemary Jackson, Fantasy: The Literature of Subversion (London: Methuen, 1981), pp. 25-26.

${ }^{8}$ Racconti neri della scapigliatura, ed. by Gilberto Finzi (Milan: Mondadori, 1980), pp. 9-10 (my emphasis).

${ }^{9}$ Ibid., p. 10.

${ }^{10}$ Francesco Ruchin, Iginio Ugo Tarchetti : anatomia di un'anima (Prato: Pentalinea, 2011), pp. 103-05.

${ }^{11}$ The corpus of texts I will examine comprises Racconti fantastici (1869) - 'Le leggende del castello nero' (1867), 'I fatali' (1869), 'La lettera U (Manoscritto d'un pazzo)' (1869), 'Un osso di morto' (1869), and 'Uno spirito in un lampone' (1869) - together with 'L'elixir dell'immortalità (Imitazione dall'inglese)' (1865), 'Riccardo Waitzen' (1867), 'Il lago delle tre lamprede (Tradizione popolare)' (1868), and 'Re per ventiquattrore (Storia di un giorno della mia vita)' (1869).

${ }^{12}$ Enrico Ghidetti, '"Forze occulte»: scienza, spiritismo e letteratura fantastica al tramonto del secolo XIX', in Italia magica: letteratura fantastica e surreale dell'Ottocento e del Novecento: atti del convegno, Cagliari-Pula 7-10 giugno 2006, ed. by Giovanna Caltagirone and Sandro Maxia (Cagliari: AM\&D, 2008), pp. 29-48 (p. 34).
} 
${ }^{13}$ David Del Principe, Rebellion, Death, and Aesthetics in Italy: The Demons of Scapigliatura (Madison: Fairleigh Dickinson University Press, 1996), p. 80.

${ }^{14}$ Ruchin, Iginio Ugo Tarchetti, p. 113.

${ }^{15}$ Tzvetan Todorov, The Fantastic: a Structural Approach to a Literary Genre, trans. by Richard Howard (Ithaca, N.Y: Cornell University Press, 1975), p. 110.

${ }^{16}$ Ibid., p. 113.

${ }^{17}$ Igino Ugo Tarchetti, Tutte le opere (II), ed. by Enrico Ghidetti (Bologna: Cappelli, 1968), p. 10.

${ }^{18}$ Ibid., p. 45

${ }^{19}$ Ibid., p. 64.

${ }^{20}$ Ibid., p. 65.

${ }^{21}$ Ibid., p. 73

${ }^{22}$ Igino Ugo Tarchetti, Tutte le opere (I), ed. by Enrico Ghidetti (Bologna: Cappelli, 1968), p. 114.

${ }^{23}$ Ibid., p. 605.

${ }^{24}$ Ibid., p. 204

${ }^{25}$ For a discussion of the realisms in Tarchetti's work see Piero Pieri, 'Il fantastico di Tarchetti tra realismo autobiografico e verismo stilistico', in I/ visionario, il fantastico, il meraviglioso tra otto e novecento, ed. by Angelo Mangini and Luigi Weber, 2. ed. (Ravenna: Allori, 2006), pp. 99-133; and Umberto Bosco, Realismo romantico (Roma: S. Sciascia, 1959), pp. 127-37.

${ }^{26}$ Vittorio Roda, I fantasmi della ragione: fantastico, scienza e fantascienza nella letteratura italiana fra Otto $e$ Novecento (Napoli: Liguori, 1996), p. 80.

${ }^{27}$ Bonifazi, Teoria del fantastico, p. 89.

${ }^{28}$ In a footnote, Ghidetti gives further biographical details: 'Heinrich Cornelius Agrippa von Nettesheim (Colonia, 1486-Grenoble, 1535), mago, scienziato, avventuriero, dottore in teologia [...].' Tarchetti, opere (I), p. 115. n2.

${ }^{29}$ Fred Botting, Gothic (London; New York: Routledge, 1996), pp. 2-3.

${ }^{30}$ Fred Botting, 'In Gothic Darkly: Heterotopia, History, Culture', in A companion to the Gothic, ed. by David Punter (Oxford; Malden, Mass.: Blackwell Publishers, 2000), pp. 3-14 (p. 9).

${ }^{31}$ Indeed this takes place on a geographic scale. Radcliffe and Walpole use Italy as a spaces for the gothic, deferred from an English speaking and Anglophone country setting, displaced not only by distance but also but by culture and language. Finné argues that Italy is a common setting for gothic writers (such as Walpole, Radcliffe, Hawthorne) because of its perceived mysterious [and by extension 'other'] quality. L'Italie fantastique de Boccacio à Landolfi : anthologie établie et présentée par Jacques Finné, ed. by Jacques Finné (Verviers: André Gérard), p. 9.

${ }^{32}$ Ann Hallamore Caesar, 'Sensation, Seduction, and the Supernatural: Fogazzaro's Malombra', in The Italian Gothic and Fantastic: Encounters and Rewritings of Narrative Traditions, ed. by Francesca Billiani and Gigliola Sulis (Madison, NJ: Fairleigh Dickinson University Press, 2007), pp. 98-118 (p. 104).

${ }^{33}$ Botting, Gothic, p. 6.

${ }^{34}$ Ibid., p. 113.

${ }^{35}$ The aristocrat is a staple figure of early gothic, which is also present in 'I fatali' in the characters of Saternez and Sagrezwitch.

${ }^{36}$ For further discussion of the Gothic in Tarchetti, see David Del Principe, Rebellion, Death, and Aesthetics in Italy: The Demons of Scapigliatura (Madison: Fairleigh Dickinson University Press, 1996), pp. 75-109; 'The Reality of Ugo Tarchetti's Gothic', Gothic Studies, 8 (2006), 52-67; and Francesca Billiani, 'Delusional Identities: The Politics of the Italian Gothic and Fantastic in Igino Ugo Tarchetti's Trilogy Amore nell'arte and Luigi Gualdo's Short Stories,

"Allucinazione", "La Canzone Di Weber" and "Narcisa"', Forum for Modern Language Studies, 44 (2008), 480-99.

${ }^{37}$ Tarchetti, opere (II), p. 9.

38 Ibid., p. 40.

${ }^{39}$ Ibid., pp. 61-62.

${ }^{40}$ Ibid., pp. 64, 57.

${ }^{41}$ This argument is adapted from that made by Susan Stewart in her book on nonsense. Susan Stewart, Nonsense: Aspects of Intertextuality in Folklore and Literature (Baltimore: Johns Hopkins University Press, 1978), p. 6.

${ }^{42}$ Bruno Galvani, Igino Ugo Tarchetti nel centenario della morte (Alessandria: I'amministrazione provinciale, 1969), p. 10.

${ }^{43}$ Tarchetti, opere (II), p. 59.

44 Ibid., p. 56.

45 Ibid., p. 65.

${ }^{46}$ Ibid., p. 106.

${ }^{47}$ Enrico Ghidetti, Tarchetti e la Scapigliatura lombarda (Napoli: Libreria scientifica editrice, 1968), p. 237.

${ }^{48}$ Tarchetti, opere (I), p. 114.

${ }^{49}$ Ibid., p. 115. 
${ }^{50}$ Ibid., p. 126.

51 '[h]ai dormito un giorno intero'. Ibid., p 244.

${ }^{52}$ Vittorio Roda, Homo duplex: scomposizioni dell'io nella letteratura italiana moderna (Bologna: Il Mulino, 1991), p. 41.

53 Marziano Guglielminetti, 'Il sociale, l'umoristico, il fantastico ed altro nell'opera di Igino Ugo Tarchetti', in Igino Ugo Tarchetti e la Scapigliatura: atti del convegno nazionale, S. Salvatore Monferrato, 1-3 ottobre 1976 (Alessandria: Cassa di Risparmio, 1977), pp. 15-44 (p. 31).

${ }^{54}$ Tarchetti, opere (I), p. 204.

${ }^{55}$ Ibid.

56 Filippo Bettini, 'Le componenti «avanguardistiche » della narrativa di Tarchetti: tra novità ideologica e sperimentazione linguistica', in Igino Ugo Tarchetti e la Scapigliatura: atti del convegno nazionale, S. Salvatore Monferrato, 1-3 ottobre 1976 (Alessandria: Cassa di Risparmio, 1977), pp. 241-54 (p. 249).

${ }^{57}$ Tarchetti, opere (I), pp. 604-05.

${ }^{58}$ Ghidetti, Scapigliatura lombarda, p. 213.

59 Antonella Santoro, 'Appunti sui «Racconti fantastici» di Igino Ugo Tarchetti', in Italia magica: letteratura fantastica e surreale dell'Ottocento e del Novecento: atti del convegno, Cagliari-Pula 7-10 giugno 2006, ed. by Giovanna Caltagirone and Sandro Maxia (Cagliari: AM\&D, 2008), pp. 68- 80 (p. 69).

${ }^{60}$ Bosco, Realismo romantico, pp. 129-30.

${ }^{61}$ Tarchetti, opere (II), p. 8 (my emphasis).

${ }^{62}$ Guglielminetti, 'Il sociale, l'umoristico, il fantastico', p. 29.

${ }^{63}$ Tarchetti, opere (I), p. 601 (original emphasis).

${ }^{64}$ Tarchetti, opere (II), p. 66.

65 Ibid., p. 65.

${ }^{66}$ Ruchin, Iginio Ugo Tarchetti, p. 111.

${ }^{67}$ Mariella Colin, 'La difficile naissance de la littérature fantastique en Italie', Les langues néo-latines, 272 (1990), pp. 73-96 (p. 89).

${ }^{68}$ Moretti, 'Igino Ugo Tarchetti e il racconto fantastico', p. 107.

${ }^{69}$ Tarchetti, opere (II), p. 33 (original emphasis).

${ }^{70}$ Ibid. (my emphasis).

71 lbid., p. 32.

72 Ibid., p. 7.

73 lbid., p. 13.

${ }^{74}$ Ibid., p. 15-16.

${ }^{75}$ Ibid., p. 40.

${ }^{76}$ Bonifazi, Teoria del fantastico, p. 90.

77 Ibid.

${ }^{78}$ Tarchetti, opere (II), p. 31.

${ }^{79}$ Ibid., p. 61.

${ }^{80}$ The monks remain incarcerated as lampreys in a lake, trapped in the very substance they refused to give away, echoing the manner in which the contrapassi in Dante's Inferno reflect the crime committed. That the narrator is lost in a dark wood further alludes to Dante and to a narrative universe by definition overseen by an omnipotent and omnipresent deity. By extension, it can be argued that Dante's Commedia is an exploration in the complexities of pan-determinism.

${ }^{81}$ In order to discuss Tarchetti this claim suffices, but it would be prudent to add a caveat acknowledging the possibility of a fantastic narrative where this rule does not apply.

82 Roda, Studi sul fantastico, p. 20.

${ }^{83}$ Tarchetti, opere (I), p. 609.

${ }^{84}$ Ruchin, Iginio Ugo Tarchetti, p. 163 (my emphasis). 